\title{
Studies on virginiamycin in growing rabbits
}

\author{
F. M. SOLCA, Fabia ROSI, Claudia NORDIO BALDISSERA \\ Istitudo di Zootecnia generale, Cattedra di Anatomia e Fisiologia degli \\ animali domestici-Facolta di Agraria, Via Celoria 2 Milano (Italy)
}

Three groups of N.Z.W. female rabbits fed for $17-3 \mathrm{I}-45-52-59-66-73$ days with a diet containing $o-x o-20 \mathrm{ppm}$ of Virginiamycin respectively, were analysed to study the differences in animal performances. Live weight, cold carcass weight, $4 / 4$ weight, bodyweight increase, feed conversion ratios and slaughtering yield were considered. No significant differences were observed from the variance analysis with the administration of the three levels of Virginiamycin.

\section{Sensitivity of rabbit to ampicillin, gentamicin and their association}

\author{
L. ESCOULA, R. CAMGUILHEM, G. LARRIEU, J. MORÉ \\ Station de Pharmacologie-Toxicologie, I.N.R.A., I80, chemin de Tournefeuille \\ 3I 300 Toulouse (France)
}

Oral administration of either Ampicillin (20 mg/ $/ \mathrm{kg}$ ), Gentamicin (Io $\mathrm{mg} / \mathrm{kg}$ ) or both to growing rabbits resulted in a weight $\operatorname{loss}(5$ to $6 \mathrm{p}$. IOo) due to a decrease in feed intake.

Ampicillin induced a reduction in volatile fatty acid production and the caecal storage of ammonia; it allowed the overgrowth of Enterobacter aerogenes. Only Gentamicin could be detected in various organs of rabbits twenty four hours after the last administration.

\section{Incorporation of straw into growing rabbit diets}

\author{
P. MERCIER (1), Madeleine SEROUX (2), Y. FRANCK ( $\left.{ }^{3}\right)$ \\ (I) UFAC, Service Cunicole, 95450 Vigny (France). \\ (2) ITCF, Station expérimentale, Boigneville, 9I720 Maisse (France). \\ (3) ITAVI, Service Technique, 28, rue du Rocher, 75008 Paris (France).
}

Five experiments were made to study the possible incorporation of straw treated with 2 p. Ioo sodium hydroxyde compared with untreated and ground straw. The diets for fattening rabbits contained 10,20 or 30 p. Ioo straw.

Growth was not affected by the percentage of straw, treated or not, but the daily feed intake and the conversion ratio increased linearly with the straw content of the diet.

The economic interest of this raw material is discussed. 